\title{
Analysis of Brazilian species of Pelecitus Railliet \& Henry (Nematoda, Filarioidea) with the establishment of new records
}

\author{
Roberto Magalhães Pinto ${ }^{1,2} \&$ Dely Noronha ${ }^{1,3}$
}

\author{
${ }^{1}$ Laboratório de Helmintos Parasitos de Vertebrados, Departamento de Helmintologia, Instituto Oswaldo Cruz. Avenida \\ Brasil 4365, 21045-900 Rio de Janeiro, Rio de Janeiro, Brasil. \\ ${ }^{2}$ Corresponding author. CNPq research fellow. E-mail: rmpinto@ioc.fiocruz.br \\ ${ }^{3}$ Curator of the Helminthological Collection of the Oswaldo Cruz Institute.
}

\begin{abstract}
Data on nematodes of the genus Pelecitus Railliet \& Henry, 1910, namely P. fulicaeatrae (Diesing, 1851) López-Neyra, 1956, P. anhingae Vuylsteke, 1957, P. tubercauda Vanderburgh, Anderson \& Stock, 1984, P. vuylstekae (Molin, 1860) Bartlett \& Greiner, 1986, P. tercostatus (Molin, 1860) Railliet \& Henry, 1910, P. helicinus (Molin, 1860) Railliet \& Henry, 1910, P. circularis (Molin, 1860) Railliet \& Henry, 1910 and Pelecitus sp., are presented, with basis on 29 nematode samples recovered from Brazilian birds representing 13 families and 19 species that were captured between 1934-1951 in the southeastern and central regions; parasites were formerly deposited as unidentified material in the Helminthological Collection of the Oswaldo Cruz Institute.
\end{abstract}

KEY WORDS. Brazil, birds, Nematodes, Pelecitus.

Recently, ONIKI et al. (2002) stated that in many South American countries, except for the Brazilian studies, the knowledge of the biodiversity in Neotropical birds is poor and that data on parasite distribution, prevalence and life cycles lack for common species.

The present investigation was scheduled to add new data on avian nematodes that have widely been referred in our country in extensive previous studies. Nevertheless, nematodes of the genus Pelecitus Railliet \& Henry, 1910 have not been routinely reported; this may be due to the fact that these parasites occur in sites (muscles, tendons and nodules of the legs and feet or footpads), seldom considered during bird necropsies.

For this reason, samples of these nematodes are herein identified, in an effort to extend the list of known Pelecitus species and also to establish new host records for these parasites that represent the most widely distributed avian filarioids known; moreover, according to BARTLETT \& GREINER (1986) they can be of zoonotic importance in South America, since there is evidence for the infection of mammals with filarioids from birds in this region.

\section{MATERIAL AND METHODS}

Twenty- nine nematode samples were collected between 1934-1951 from avian hosts during institutional scientific expeditions to the southeastern and central Brazilian regions and deposited as unidentified material in the Helminthological Collection of the Oswaldo Cruz Institute (CHIOC) as wet material, preserved in Railliet \& Henry's solution.

Hosts: the studied nematodes were recovered from specimens of the following birds: Aramides cajanea Müller, 1776, Belonopterus chilensis Wagler, 1827, Brotogeris versicolorus (Müller, 1776), Butorides striatus (Linnaeus, 1758), Cacicus solitarius (Vieillot, 1819), Campephilus melanoleucos (Cory, 1915), Cyanocorax cyanomelas (Vieillot, 1818), Cyanocorax crysops (Vieillot, 1818), Euxenura maguari Gmelin, 1789, Gubernatrix cristata (Vieillot, 1817), Jabiru mycteria (Lichtenstein, 1819), Milvago chimachima (Vieillot, 1816), Nycticorax nycticorax (Gmelin, 1789), Ortallis canicollis Cherrie \& Reichenberger, 1921, Paroaria sp., Pipile cumanensis (Jacquin, 1784), Pteroglossus aracari (Linnaeus, 1758), Sarcoramphus papa (Linnaeus, 1758) and Syrigma sybilatrix (Temminck, 1824).

Parasites: for study, nematodes were either dehydrated in ethanol $70^{\circ}-100^{\circ} \mathrm{GL}$, stained with alcoholic carmine and clarified in beechwood creosote or were directly clarified in acetic acid plus phenol, unstained. After study and by means of regressive processes, nematodes were returned to the vials with the original preservative solution. Specimens of some samples were preserved in Canada balsam as whole mounts. Classification of nematodes and morphological terminology follow BartLett \& Greiner (1986); classification and common 
names of hosts are in accordance with PINTO $(1944,1978)$, FRISCH (1981) and SICK (2001). NFR, NHR and NGR indicate New Family Record, New Host Record and New Geographical Record, respectively. The new geographical records are only considered when a species is referred in Brazil for the first time and also, in this case, figured; the different localities of occurrences in the country were not taken into account.

\section{RESULTS AND REMARKS}

Most of the studied specimens were slightly damaged. Worms are in extremely fragile shape and, in many cases, the outermost cuticle appears to have been stripped off or peeled away. In particular this stripping has affected the tail of some males, making the papillae appear "naked", i.e. not within caudal alae. Probably, this is an artifact as in some cases the delicate peeled cuticle is still attached via a thin strip to the worms themselves and this stripping or peeling may be due to a harsh preservative (possibly acid-based) in which the specimens may have been stored at some time in the past. Morphology refers to general characters.

\section{Pelecitus fulicaeatrae (Diesing, 1861) López-Neyra, 1956 Figs 1-3}

Largish nematodes with cephalic papillae not protuberant. Configuration of male 3.5 tight helical turns and that of females 2-2.5 loose or tight helical turns. Vulva protuberant with downslanted opening and overhung upper lip. Spicules unequal, lamina of left delicate.

Host: Aramides cajanea Müller, 1776. Rallidae; common names: gray-necked wood-rail, "sanã, sericoia, saracura, trêspotes" (NHR), Jabiru mycteria (Lichtenstein, 1819). Ciconiidae; common names: jabiru stork, "tuiuiú, jaburu" (NHR).

Site of infection: foot-pad.

Locality: Salobra, Mato Grosso do Sul, Brazil (NGR).

Deposited: CHIOC no. 11600 (2 females) - wet material; 14209 ( 2 females, 1 male) - wet material, presently unavailable. Remark: this species occurs in representatives of several families, including other Rallidae birds. Podicipedidae, Anatidae, Acciptridae, Coraciidae, Ardeidae, Pandionidae and Laridae hosts are also referred, distributed in Britain, Germany, Russia, Japan, France, Canada and Madagascar (Bartlett \& GREINER 1986).

\section{Pelecitus anhingae Vuylsteke, 1957 (Figs 4-6)}

Largish nematodes with protuberant cephalic papillae. Configuration of males consists of 1.5 loose helical turns and that of females by 1.5-2 loose open circles. Vulva protuberant with downslanted opening and overhung upper lip. Spicules unequal, lamina of left delicate. Pattern of caudal papillae with large and small groups.

Host: Sarcoramphus papa (Linnaeus, 1758), Cathartidae (NFR); common names: king vulture, "urubu-rei"

Site of infection: tendons of feet.

Locality: rio Aquidauana, Mato Grosso do Sul, Brazil-NGH.

Deposited: CHIOC no. 34385 a-f (2 males, 4 females) whole mounts.

Remark: this is the first report of this species occurring in other host than the type, that is an Anhingidae from the Garamba National Park in the Zaire, Africa (BARTLETT \& GReINER 1986).

\section{Pelecitus tubercauda Vanderburgh, Anderson and Stock, 1984 (Figs 7-9)}

Medium sized worms, with cephalic papillae not protuberant. Configuration of males is 2.5 helical turns and that of females 2-3 helical turns. Vulva protuberant with central opening. Males with subequal spicules, lamina of left stout. Papillae of variable size divided into large and small groups.

Host: Cacicus solitarius (Vieillot, 1819), Icteridae; common names: solitary black cacique, "iraúna-de-bico-branco" (NHR).

Site of infection: tendons of legs.

Locality: Salobra, Mato Grosso do Sul, Brazil (NGR). material.

Deposited: CHIOC no. 11523 (2 males, 3 females), wet

Remark: this species had only been previously referred in a Parulidae host, Geothlypis trichas (Linnaeus, 1758) from Canada (BarTletT \& GReiner 1986).

\section{Pelecitus vuylstekae (Molin, 1860) Bartlett \& Greiner, 1986 (Figs 10-12)}

Largish nematodes with protuberant cephalic papillae as blunt stubs. Strong muscular striations. Configuration of males as a long twisted $\mathrm{C}$ and that of females, a long curved or almost closed C. Vulva protuberant with downslanted opening and overhung upper lip. Spicules unequal, lamina of left delicate. Papillae pattern with large and small groups plus inclusions.

Host: Syrigma sybilatrix (Temminck, 1824), Ardeidae; common names: whistling heron, "maria-faceira".

Site of infection: tendons of feet.

Locality: Barranco Alto, Mato Grosso do Sul - Brazil (NGR).

Deposited: CHIOC no. 14602 (3 males, 2 females), 15092 - wet material.

Remark: this species had only been reported from an African Ardeidae and nematodes of the studied sample (14602 from $S$. sybilatrix) were previously referred to as Pelecitus sp. by ARruda et al. (2001).

\section{Pelecitus helicinus (Molin, 1860) Railliet \& Henry, 1910}

Large nematodes with cephalic papillae not protuberant. Configuration of males represented by 4.5 tight helical turns and that of females 2-3 helical turns. Vulva not protuberant. Spicules subequal, lamina of left stout. Caudal papillae of variable size, not divided into large and small groups.

Host: Pteroglossus aracari (Linnaeus, 1758). Ramphastidae; common names: black-necked aracari, "araçari" (NHR).

Site of infection: tendons of feet.

Locality: Raul Soares, Minas Gerais, Brazil. material.

Deposited: CHIOC no. 20064 (2 males, 5 females) - wet

Remark: Pelecitus helicinus is widely distributed; other hosts and localities were previously referred by BARTLETT \& Greiner (1986), Pinto et al. (1993), Vicente et al. (1995), OniKi et al. (2002).

\section{Pelecitus circularis (Molin, 1860) Railliet \& Henry, 1910}

Smalish nematodes with cephalic papillae not protuberant. Configuration of males an open $\mathrm{C}$ or small knots and that of females small loose 6 , small loose almost closed C, 1.53 medium to tight circles, 2 tight circular knots. Vulva protu- 


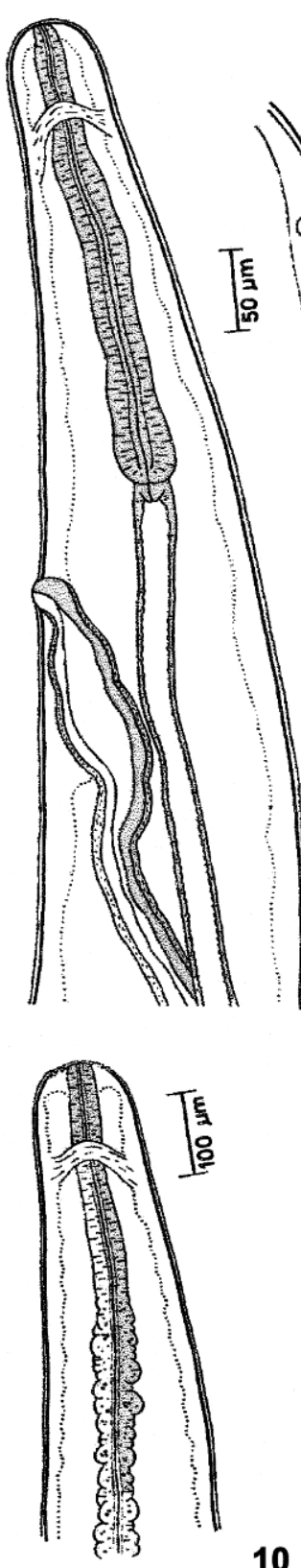

10

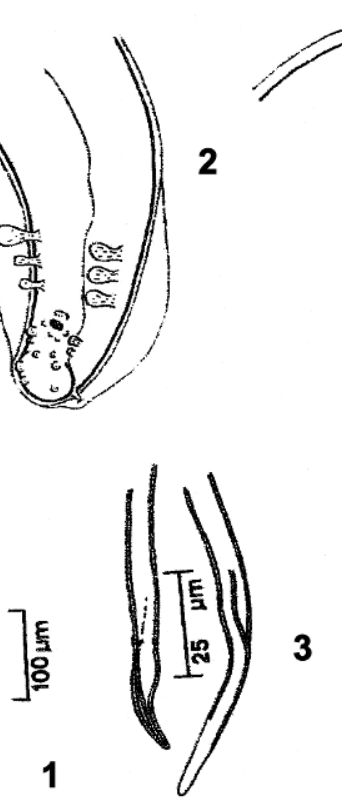

.

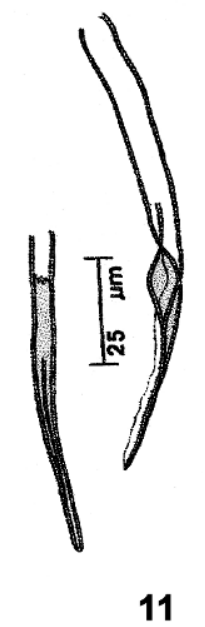

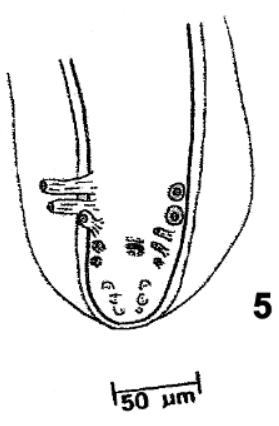
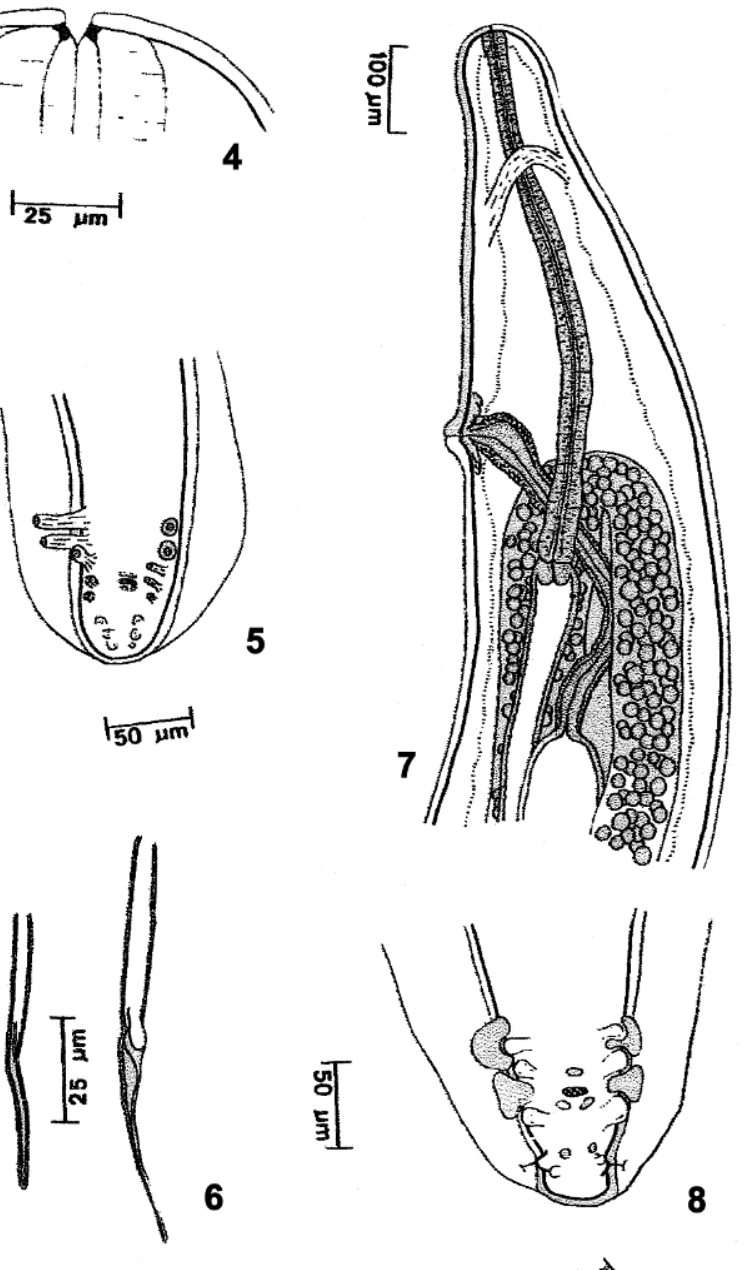

Figures 1-12. (1-3) Pelecitus fulicatrae: (1) female, anterior portion, lateral view; (2) tail of male, ventral view; (3) spicules, right and left, ventral view; (4-6) Pelecitus anhingae: (4) male, cephalic extremity, lateral view; (5) tail of male, ventral view; (6) spicules, right and left, ventral view; (7-9) Pelecitus tubercauda: (7) female, anterior portion, lateral view; (8) tail of male, ventral view; (9) spicules, right and left, ventral view; (10-12) Pelecitus vuylstekae: (10) male, anterior portion, lateral view; (11) spicules, right and left, lateral view; tail of male, ventral view. Modified and adapted after BartLett \& Greiner (1986).

berant with central opening. Spicules subequal, lamina of left stout. Caudal papillae of variable size, not divided into large and small groups.

Hosts: Campephilus melanoleucos (Cory, 1915). Picidae; common names: crimson-crested woodpecker, "pica-pau-real" (NHR), Euxenura maguari Gmelin, 1789. Ciconiidae; common names: "baguari, cauauã, jaburu-moleque, cegonha" (NHR), Ortallis canicollis Cherrie \& Reichenberger, 1921. Cracidae; 
common names: chaco chachalaca, " aracuã-do-Pantanal” (NHR), Cyanocorax cyanomelas (Vieillot, 1818). Corvidae; common names: purplish jay "gralha púrpura", Cyanocorax crysops (Vieillot, 1818). Corvidae; common names: plushcrested jay, "gralha-de-crista-negra".

Site of infection: among tendons of feet.

Localities: Barranco Alto and Salobra, Mato Grosso do Sul, Brazil.

Deposited: CHIOC no. 11514 (2 females), 12959 (3 females), 13019 ( 1 male, 2 females), 14557 ( 1 female), 14605 ( 2 males, 2 females), 15079 ( 3 males, 3 females), 15082 ( 1 male, 3 females), 15088 ( 1 male, 3 females), 15093 (2 tiny females) - wet material; 34380 a, b, 34383 a-c, 34388 a-e- whole mounts.

Remark: other hosts and localities for $P$. circularis are in Bartlett \& Greiner (1986), Pinto et al. (1993) and Vicente et al. (1995).

\section{Pelecitus tercostatus (Molin, 1860) Railliet \& Henry, 1910}

Largish nematodes. Configuration of males and females corresponds to a loose twisted $\mathrm{C}$ and a straight open 6 , respectively. Vulva protuberant with overhung upper lip. Spicules unequal, lamina of left delicate.

Host: Brotogeris versicolorus (Müller, 1776). Psittacidae; common names: canary-winged parakeet, "periquito-de-asasamarelas" (NHR).

Site of infection: tendons of feet.

Locality: Ilha Seca, São Paulo, Brazil.

Deposited: CHIOC no. 11792 (3 females), 11793 ( 2 males, 3 females) - wet material; 34381 a-b, 34382 a-b - whole mounts. Remark: the same as stated for $P$. circularis.

Infections with Pelecitus sp. are referred for the first time in Butorides striatus (Linnaeus, 1758), Nycticorax nycticorax (Gmelin, 1789), Syrigma sybilatrix (Temminck, 1824) - Ardeidae, Pipile cumanensis (Jacquin, 1784) - Cracidae, Milvago chimachima (Vieillot, 1816) - Falconidae, Belonopterus chilensis Wagler, 1827

- Charadriidae (NFR), Gubernatrix cristata (Vieillot, 1817), Paroaria sp. - Fringillidae (NFR).

The present results add Pelecitus anhingae, $P$. fulicaeatrae, P. tubercauda, P. vuylstekae, Pelecitus sp. and new hosts to the list of Brazilian Pelecitus species previously reported and that includes $P$. andersoni Bartlett \& Greiner, 1986, $P$. circularis, $P$. helicinus, $P$. tercostatus (the latter three also considered in the present study), Pelecitus sp.: Travassos, 1941, Pelecitus sp.: Travassos \& Freitas, 1941 and Pelecitus sp.: Pinto, Vicente \& Noronha, 1993 (VICENTE et al. 1995).

\section{ACKNOWLEDGEMENTS}

To Dr. Cheryl M. Bartlett, from the University College of Cape Breton, Nova Scotia, Canada, for the preliminary selection of the nematode samples and valuable scientific information.

\section{REFERENCES}

Arruda, V.S.; R.M. Pinto \& L.C. Muniz-Pereira. 2002. New host and geographical records for helminths parasites of Ardeidae (Aves, Ciconiiformes) in Brazil. Revista Brasileira de Zoologia, Curitiba, 18 (Supl. 1): 225-232.

Bartlett, C.M. \& E.C. Greiner. 1986. A revision of Pelecitus Railliet \& Henry, 1910 (Filarioidea, Dirofilariinae) and evidence for the "capture" by mammals of filarioids from birds. Bulletin du Muséum National d'Histoire Naturelle, Paris, 8 (1): 47-99.

Frisch, J.D. 1981. Aves Brasileiras. São Paulo, Dalgas-Ecoltec Ecologia Técnica e Comércio Ltda, 353p.

ONIKI, Y.; J.M. KInsella \& E.O. Willis. 2002. Pelecitus helicinus Railliet \& Henry, 1910 (Filarioidea, Dirofilariinae) and other nematode parasites of Brazilian birds. Memórias do Instituto Oswaldo Cruz, Rio de Janeiro, 97 (4): 597-598.

PinTo, O.M.O. 1944. Catalogo das aves do Brasil. São Paulo, Secretaria da Agricultura, Industria e Comércio, 699p.

- 1978. Novo catálogo das aves do Brasil. São Paulo, Empresa Gráfica da Revista dos Tribunais, XIII+446p.

Pinto, R.M.; J.J. Vicente \& D. Noronha. 1993. Nematode parasites of Brazilian psittacid birds, with emphasis on the genus Pelecitus Railliet \& Henry, 1910. Memórias do Instituto Oswaldo Cruz, Rio de Janeiro, 88 (2): 279.

SICK, H. 2001. Ornitologia brasileira. Rio de Janeiro, Editora Nova Fronteira, 862p.

Vicente, J.J.; H.O. Rodrigues; D.C. Gomes \& R.M. Pinto. 1995. Nematóides do Brasil. Parte IV: Nematóides de aves. Revista Brasileira de Zoologia, Curitiba, 12 (Supl. 1): 1-273.

Received in 25.XI.2002; accepted in 02.VI.2003. 